\title{
Friedrich Nietzsche: the wandering and learned neuropath under Dionisius
}

\author{
Friedrich Nietzsche: o neuropata culto e vagante sob Dionísio
}

Marleide da Mota Gomes

\begin{abstract}
Friedrich Nietzsche (1844-1900) was a remarkable philologist-philosopher while remaining in a condition of ill-health. Issues about his wandering/disruptive behavior that might be a consequence and/or protection against his cognitive decline and multifaceted disease are presented. The life complex that raises speculations about its etiology is constituted by: insight, creativity and wandering behavior besides several symptoms and signs of disease(s), mainly neurological one. The most important issue to be considered at the moment is not the disease diagnosis (Lissauer's general paresis or CADASIL, e.g.), but the probable Nietzsche's great cognitive reserve linked to the multifactorial etiology (genetic and environmental), and shared characteristics both to creativity and psychopathology. This makes any disease seems especial regarding Nietzsche, and whichever the diagnostic hypothesis has to consider the Nietzsche's unique background to express any disease(s).
\end{abstract}

Keywords: Friedrich Nietzsche, Lissauer's general paresis, CADASIL, creativity, cognitive reserve, embodied cognition.

RESUMO

Friedrich Nietzsche (1844-1900) foi um notável filólogo-filósofo enquanto mantinha-se em uma condição de saúde precária. São apresentadas questões sobre seu comportamento errante/disruptivo que podem ser uma consequência e/ou protecção contra seu declínio cognitivo e doença multifacetada. O complexo de vida que levanta especulações sobre sua etiologia é constituído por: insight, criatividade e comportamento errante, além de vários sintomas e sinais de doença(s) principalmente neurológicas. A questão mais importante a ser considerada no momento não é o diagnóstico da doença (Paralisia geral de Lissauer ou CADASIL, por exemplo), mas a grande reserva cognitiva de Nietzsche ligada à etiologia multifatorial (genética e ambiental) e as características comuns tanto para criatividade ou psicopatologia. Isso faz com que qualquer doença do filósofo se expresse de forma especial, e qualquer que seja a hipótese diagnóstica tem que considerar a base especial de Nietzsche para expressar qualquer doença(s).

Palavras-chave: Friedrich Nietzsche, paralisia geral de Lissauer, CADASIL, criatividade, reserva cognitiva, cognição incorporada.

Friedrich Nietzsche (Röcken bei Lützen,1844-Weimar, 1900) was a learned German philologist and revolutionary thinker who still in life have recognized his brilliance with his sister and friends support ${ }^{1}$ (Figure). He has a worldwide historical influence in consequence of his iconoclastic and innovative ideas deep rooted in the ancient Greece. Regarding his background, he had strong Lutheran tradition, and especially from his father, musical ability. In spite of this deep and stable background, he had an uneven health and peculiar life-style. Particularly, Nietzsche's thought and habits of walking leads to think on creativity, and in consequence also on a healing process supported by Hippocrates aphorism - "Walking is man's best medicine" ${ }^{2,3}$. Both ill health and habits, mainly nomadism and walking vs. creativity, namely, embodied cognition ( formative role the environment plays in the development of cognitive processes), are the leitmotif of this paper.

\section{SCHOOL BRILLIANCE, LONG LIFE HEALTH DECLINING, CREATIVITY AND WALKING}

Nietzsche was a brilliant student of classical disciplines, but Mathematics was his worst subject ${ }^{1}$. Regarding his handwriting, it was never very good, and it became even worse, as Nietzsche eyesight deteriorated ${ }^{1}$. More particularly about his long life declining health, it gave to him many suffering, but also the liberty and opportunities for his creative talent. He had to resign at age 34 (1879), from the Basel University Chair of Philology where he followed an academic life since the age of $24^{1}$. This happened mainly because 


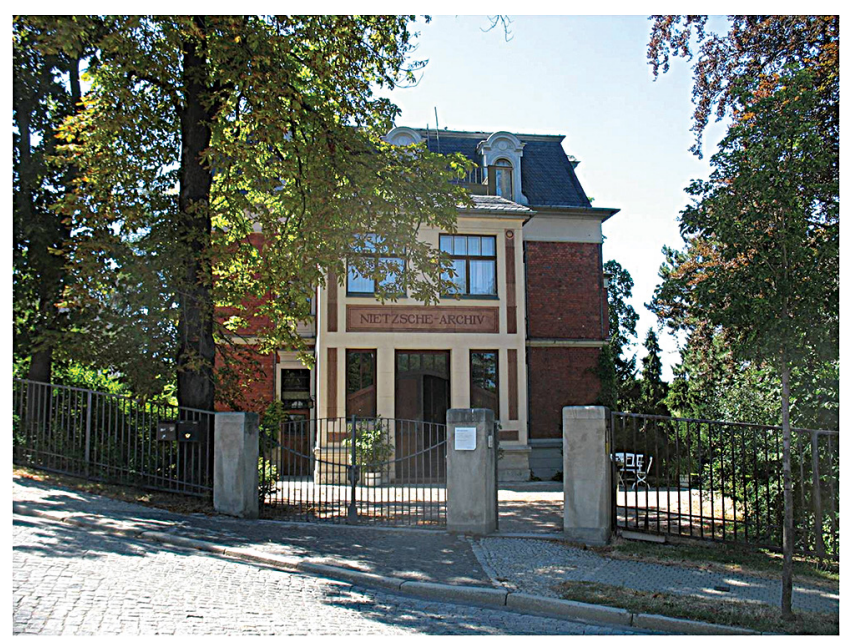

Figure. Nietzsche Archive at Weimar (http://en.wikipedia.org/ wiki/Nietzsche-Archiv) since 1896, previously in Naumburg (1894-1896), under its founder rule for many years, Elisabeth Förster-Nietzsche (1846-1935). The misconception about Nietzsche's thought what is "power", favoured Elizabeth, a widow of an anti-semitic, to help the Nazi teutonic mythmanufacturers, as explained by Hollingdale ${ }^{1}$

of his severe migraine episodes, but from 1880 until his collapse, Nietzsche led a nomadic life exactly in the years of his main works. This background conducts Nietzsche to deep feelings, to get in touch with the nature, and also the solitude, contemplation and reasoning frequently by means of his very usual and lifelong walking habits (Box 1). These altogether may be a potential creativity catalyzer, and a conductor of his admiration to Dionysius: "...that seriously wonderful phenomenon, which bears the name of Dionysus: it is only explained by an excess of power"4. Indeed, the Dionysian phenomenon, forms the cornerstone of Nietzsche's whole philosophic enterprise, represents his own energy, joy, and suffering, besides he considered himself as "...a disciple of the philosopher Dionysus, I would rather even be a satyr than a saint.". Regarding, creativity and psychopathological tint, Nietzsche's characteristics, both may have common biological determinants. This may configure a model such as one of shared biological vulnerability, as presented by Carson ${ }^{6}$. This encompass characteristics like stimuli into conscious awareness, an attentional style driven by novelty importance, and neural hyperconnectivity that may increase associations among disparate stimuli. More specifically, Andreasen, apud Carson ${ }^{6}$, found that there is a interrelation among mood disorders, creative interests and families, concluding that "affective disorder may be both a 'hereditary taint' and a hereditary gift." In addition, several studies already demonstrated that participants were more creative walking than sitting, and walking may be effective in many locations that do not have acute distractions ${ }^{3}$. There are also studies that have shown global protective effects of exercise against cognitive decline ${ }^{3}$. Walking may have also increased the ease with which associative memories are activated, for example, by relaxing inhibitory competition among memories and allowing ideas with low levels of activation to push through, as presented by Oppezzo et al. ${ }^{3}$.

\section{NIETZSCHE'S DIAGNOSTIC DISEASE PUZZLE}

In January 1889, Nietzsche experienced a final mental collapse, the edge between his unstable health and the invalidity for the rest of his life. In Turin, he was found creating such a disturbance, and his behavior demonstrated complete mental breakdown, although he was physically well ${ }^{1}$. After a week hospitalization in Basel, he spent 1889 in a sanatorium in Jena at the Binswanger Clinic, and in March 1890 his mother took him back home to take care of him. In the first two years at home, the apathy gradually developed, but he did not give the appearance of suffering ${ }^{1}$. Nietzsche died near his 56th year, apparently of pneumonia in combination with a last and final stroke. The original diagnosis of the doctors in Basel and in Jena asylum headed by Otto Binswanger was brain syphilitic infection, mainly because of the higher diagnostic probability of this disease at the time, and Nietzsches pupilar anomalies (old) besides dementia ${ }^{7,8}$. Paul Julius Möbius also supported this diagnosis and even published a book Ueber das Pathologische bei Nietzsche ${ }^{8}$. However, as Sax pointed out, apud Hemelsoet ${ }^{7}$, the Houston Merritt's five cardinal signs of neurosyphilis identified from medical descriptions made upon his arrival at the asylum in Basel, Nietzsche did not show remarkable signs of the general palsy of the insane (GPI): the facial expressions remained vivid and evocative; profound reflexes were normal; tremor was not present; handwriting in the weeks and months after his collapse was unaltered; speech was fluent, although sometimes the content was bizarre. Besides, in spite of the clarity of Nietzsche's final writings the megalomania traits were patent, as seen in Ecce Homo (Why I am so wise; Why I am so clever; Why I write such excellent books... $)^{5}$. There were also strong speculations that rather than GPI, he had a longstanding progressive encephalic disease. To support this impression, there are several reports suggesting that Nietzsche had always been disturbed. The main diagnostic hypothesis for it would be Cerebral Autosomal-Dominant Arteriopathy with Subcortical Infarcts and Leukoencephalopathy (CADASIL), raised by Hemelsoet et al. ${ }^{7}$. Anyway, for this complex personage, an array of hypothesis may be presented including the Lissauer's general paresis with a protracted course as Krapellin ${ }^{9}$ presented as one type of GPI (Box 2). This can happen in a brain with vast reserve because of Nietzsches's high education, work complexity and his peculiar lifestyle that could postpone the onset of clinical dementia. This may be associated with previous comorbidities (migraine, temporal lobe epilepsy, mood disorder, severe myopia). However, in respect to the diagnostic parsimony principle, CADASIL, the main genetic cause of stroke, is the best diagnosis appraised until now.

Final remarks, Nietzsche had an excruciating, but enlightened life, with a nourishing cradle of intelligence, culture and physical fitness. Although, there was a subjacent degenerative genetic back-ground, e.g., CADASIL, or alternatively, several comorbidities summed to a more severe last one, as 
Lissauer's GPI. Either may led him to an innovative and daring style of life and work, but also progressive mental failure. However, his nomadic and walking habits, driven by his basic illness-cultural complex, included bipolar disease, helped him have an exceptional brain cognitive reserve that maintained his creativity and unstable equilibrium, and even, delayed his death.

\section{Acknowledgement}

I acknowledge with gratitude the critical review of a Portuguese version of this paper made by Prof. Dr. Gilvan Fogel, full professor of Philosophy at the Federal University of Rio de Janeiro, in addition to his enlightened considerations on the puzzling figure of Nietzsche.

Box 1. Nietzsche and his walking habits.

Several Nietzsche's thoughts demonstrated the importance of walking in his life, through his own words or by means of his characters.

Nietzsche rejected vehemently the Gustave Flaubert though “On ne peut penser et écríre quassis”. For Nietzsche, only the thoughts emerging in movement are worthwhile ${ }^{4}$.

On Ecce Homo ${ }^{5}$, Nietzsche gives several accounts on this faith: "Sit as little as possible; give credence to no thought that is not born in the open air and accompanied by free movement - in which the muscles do not also celebrate a feast”. "'On Old and New Tables" was composed during the arduous ascent from the station to the marvelous Moorish rocky haunt of Eza, - my muscular dexterity was always greatest when the creative force flowed most freely. The body is inspired: let us leave the "soul" out of it...I might often have been seen dancing; at that time I could be on the go for seven or eight hours in the mountains without a hint of fatigue. I slept well, I laughed a great deal -, I had perfect vigor and endurance”.

Regarding the messianic book, Thus Spake Zarathustra ${ }^{10}$, these habits was extensively mentioned, also by Elisabeth Förster-Nietzsche in the Introduction of How Zarathustra came into being, and also in the own words of Zaratrusta. She included this preface in December 1905, Nietzsche Archives, Weimar. She refers that her brother often used to speak of the ecstatic mood in which he wrote "Zarathustra"; how in his walks over hill and dale the ideas would crowd into his mind, and how he would note them down hastily in a note-book from which he would transcribe them on his return, sometimes working till midnight. "The fundamental idea of my work namely, the Eternal Recurrence of all things this highest of all possible formulae of a Yea-saying philosophy, first occurred to me in August 1881. I made a note of the thought on a sheet of paper, with the postscript: 6,000 feet beyond men and time! That day I happened to be wandering through the woods alongside of the lake of Silvaplana, and I halted beside a huge, pyramidal and towering rock not far from Surlei. It was then that the thought struck me. Looking back now, I find that exactly two months previous to this inspiration, I had had an omen of its coming in the form of a sudden and decisive alteration in my tastes more particularly in music. It would even be possible to consider all 'Zarathustra' as a musical composition. "In the winter of 1882-83, I was living on the charming little Gulf of Rapallo, not far from Genoa, and between Chiavari and Cape Porto Fino. My health was not very good; the winter was cold and exceptionally rainy; and the small inn in which I lived was so close to the water that at night my sleep would be disturbed if the sea were high. These circumstances were surely the very reverse of favourable; and yet in spite of it all, and as if in demonstration of my belief that everything decisive comes to life in spite of every obstacle, it was precisely during this winter and in the midst of these unfavourable circumstances that my 'Zarathustra' originated. In the morning I used to start out in a southerly direction up the glorious road to Zoagli, which rises aloft through a forest of pines and gives one a view far out into the sea. In the afternoon, as often as my health permitted, I walked round the whole bay from Santa Margherita to beyond Porto Fino. This spot was all the more interesting to me, inasmuch as it was so dearly loved by the Emperor Frederick III. In the autumn of 1886 I chanced to be there again when he was revisiting this small, forgotten world of happiness for the last time. It was on these two roads that all 'Zarathustra' came to me, above all Zarathustra himself as a type; I ought rather to say that it was on these walks that these ideas way laid me." "...My most creative moments were always accompanied by unusual muscular activity. The body is inspired: let us waive the question of the 'soul.' I might often have been seen dancing in those days. Without a suggestion of fatigue I could then walk for seven or eight hours on end among the hills. I slept well and laughed well I was perfectly robust and patient."

Nietzsche habits of walking were lifelong. Cate ${ }^{11}$ presents several remarks about it, an early sample regards the famous boarding school Pforta, an a late one, at his health irreversible decline period. The first was "Nietzsche began the midsummer vacation of 1859 in early July, leaving Pforta on foot and walking cheerfully home through the intervening woods., and the second, "During the next few months, thanks to a daily regime of long walks in the morning and again, after a siesta, in the late afternoon, Nietzsche’s outward appearance seemed to improve."

Box 1. Continue 
In summary, the theme - the wanderer, is also a constant in Nietzsche's work, even in his characters as it can be seen in the THIRD PART - XLV. THE WANDERER of Thus Spake Zarathustra ${ }^{10}$ : "Then, when it was about midnight, Zarathustra went his way over the ridge of the isle, that he might arrive early in the morning at the other coast; because there he meant to embark. For there was a good roadstead there, in which foreign ships also liked to anchor: those ships took many people with them, who wished to cross over from the Happy Isles. So when Zarathustra thus ascended the mountain, he thought on the way of his many solitary wanderings from youth onwards, and how many mountains and ridges and summits he had already climbed. I am a wanderer and mountain-climber, said he to his heart, I love not the plains, and it seemeth I cannot long sit still. And whatever may still overtake me as fate and experience a wandering will be therein, and a mountain-climbing: in the end one experienceth only oneself.'

Box 2. Nietzsche's personal and family neuropsychiatric symptomatology. Diagnostic hypothesis also included the general palsy insanity variants of Lissauer with protracted course.

\section{SYMPTOMS}

Visual symptoms (eye vision problems more at right that included myopia until right eye blindness, besides chorioretinitis); headache that started in his childhood (severe photophobia-phonophobia-nausea-vomiting, and pain at the righ side); later in the second half of his life, psychiatric illness with depression/euphoria; report of absence episodes at times; insomnia and heavy use of chloral hydrate; during his last years, progressive cognitive decline with overt megalomania, confusion, psychosis, apathy and strokes.

Family - his father had migraine and seizure episodes (staring, inability to communicate, and postictal amnesia), besides stroke and probable cognitive decline. His brother died at the age of two years, probably by fever seizure. There were psychiatric problems on both sides of his family.

\section{DIAGNOSIS}

Nietzsche's diagnosis of a protracted and focal course of GPI, is possible according to Kraepelin ${ }^{9}$ text: “...Lissauer, Starlinger and others have offered proof that the focal symptoms observed during life, the local paralyses, hemianopsia, word-deafness, mindblindness and aphasia, correspond to definite circumscribed areas of greater severity of the process in the córtex.... "Fischer has evolved still another classification partly from an anatomical, partly from a clinical standpoint. Besides the typical form, he distinguishes Lissauer's focal paresis with its various localizations in the cortex of the posterior portion, in the cerebellum or in the thalamus, then the " atypical paresis " which comprises the catatonic, senile, foudroyant and some of the tabetic forms, and finally, epileptic and stationary paresis." Nietzsche fulfill several criteria for CADASIL such as attack before 50 years old, associated to migraine, stroke events, mood disturbances, subcortical dementia, and family history ${ }^{7}$. However, Nietzsche's father died prematurely of a supposed dementia and stroke in 1849 at age 35. This precocity weakens, but not reject CADASIL etiological hypothesis. Other hypothesis were raised such as slow growing frontotemporal brain tumor (to justify behavior, headache and eye symptoms), manic psychosis and frontotemporal dementia ${ }^{7,8}$.

\section{References}

1. Hollingdale RJ. Nietzsche: the man and his philosophy. 2 nd ed. Cambridge: University Press; 1999.

2. Batman DC. Hippocrates: 'Walking is man's best medicine!'. Occup Med. 2012;62(5):320-2.

3. Oppezzo M, Schwartz DL. Give your ideas some legs: the positive effect of walking on creative thinking. J Exp Psychol Learn Mem Cogn 2014;40(4):1142-52.

4. Nietzsche F. Twilight of the idols or how to philosophize with a Hammer. Translator: Daniel Fidel Ferrer (February 2013). [cited 2015/05/16]. Available from: http://uploads.worldlibrary.net/ uploads/pdf/20130823204042twilightidols_pdf.pdf.

5. Nietzsche F. Ecce homo: how one becomes what one is. New York: Algora; 2004.
6. Carson SH. Creativity and psychopathology: a shared vulnerability model. Can J Psychiatry. 2011;56(3):144-53.

7. Hemelsoet D, Hemelsoet K, Devreese D. The neurological illness of Friedrich Nietzsche. Acta Neurol Belg. 2008;108(1):9-16.

8. Orth M, Trimble MR. Friedrich Nietzsche's mental illness - general paralysis of the insane vs. frontotemporal dementia. Acta Psychiatr Scand 2006;114(6):439-44.

9. Kraepelin E. General paresis. New York: Jurnal of Nervous and Mental Disease; 1913.

10. Nietzsche F. Thus Spake Zarathustra: a book for all and none. Translator:Thomas Common. Release Date: November 7, 2008 [EBook \#1998]Last Updated: November 5, 2012. [cited 2015/05/16]. Available from: http://www.gutenberg.org/files/1998/1998-h/1998-h.htm.

11. Cate C. Friedrich Nietzsche, Woodstock., New York: Overlook; 2005. 